\title{
INTERFACIAL PHENOMENA ON SELECTED CATHODE MATERIALS
}

\author{
Robert Kostecki, Yoshiaki Matsuo, Frank McLarnon \\ Lawrence Berkeley National Laboratory \\ Berkeley, CA 94720, USA
}

\begin{abstract}
We have carried out a series of surface studies of selected cathode materials. Instrumental techniques such as Raman microscopy, surface enhanced Raman spectroscopy (SERS), and atomic force microscopy were used to investigate the cathode surfaces. The goal of this study was to identify detrimental processes which occur at the electrode/electrolyte interface and can lead to electrode degradation and failure during cycling and/or storage at elevated temperatures
\end{abstract}

\section{INTRODUCTION}

(i) The $\mathrm{LiMn}_{2} \mathrm{O}_{4}$ spinel is of great interest as a cathode material for rechargeable lithium-ion cells because of its low cost and small environmental impact. However, it has been reported [1-20] that this material exhibits significant capacity fading during cycling or storage at elevated temperatures, which prevents its commercial use. Several mechanisms of capacity fading have been proposed, and it appears that the most important one is Mn dissolution [3-16]. It may occur via a disproportionation reaction of unstable $\mathrm{Mn}^{3+}$ to $\mathrm{Mn}^{2+}$ and $\mathrm{Mn}^{4+}$ in the presence of acid impurities or solvent oxidation products at high electrode potentials [6,8]. Manganese ion substitution by two $\mathrm{Li}^{+}$ions and formation of $\mathrm{Li}_{1+2 y} \mathrm{Mn}_{2-\mathrm{y}} \mathrm{O}_{4}$ was also proposed as a possible mechanism of $\mathrm{LiMn}_{2} \mathrm{O}_{4}$ decomposition. It was also reported that observed capacity fading exceeded that calculated from the amount of dissolved $\mathrm{Mn}$ due to increased lattice disorder in the $\mathrm{LiMn}_{2} \mathrm{O}_{4}$ structure after storage in the electrolyte at $55^{\circ} \mathrm{C}[18]$.

In our earlier work [17], we also observed delithiation of thin-film $\mathrm{Li}_{2} \mathrm{Mn}_{4} \mathrm{O}_{9}$ electrode in EC:DMC (1:1 by volume) $1 \mathrm{M} \mathrm{LiPF}_{6}$ electrolyte. Raman measurements showed clearly spontaneous conversion of the original material into $\lambda-\mathrm{MnO}_{2}$ which was covered by a thin non-conductive layer, most likely $\mathrm{Li}_{2} \mathrm{O}$. However, we couldn't detect intercalated protons in this compound

In this study, we sought to characterize the SEI layer formation process on the $\mathrm{LiMn}_{2} \mathrm{O}_{4}$ electrode at elevated temperatures. To eliminate possible side reactions we prepared thin-film $\mathrm{LiMn}_{2} \mathrm{O}_{4}$ spinel electrodes with no additives. The $\mathrm{LiMn}_{2} \mathrm{O}_{4}$ electrodes were exposed to pure dimethyl carbonate $(\mathrm{DMC})$ or to a standard $1 \mathrm{M} \mathrm{LiPF}_{6}-\mathrm{EC}: \mathrm{DMC}$ ( $1: 1$ by vol) electrolyte where $\mathrm{EC}=$ ethylene carbonate, $\mathrm{DMC}=$ di-methyl carbonate, at 55,60 and $70^{\circ} \mathrm{C}$. Surface reactions and their products were investigated by currentsensing atomic microscopy (CSAFM), Raman spectroscopy and surface enhanced Raman spectroscopy (SERS). 
(ii) A baseline Li-ion cell defined by the DOE Advanced Technology Development (ATD) Program consists of a carbon anode (negative electrode), a $\mathrm{LiNi}_{0.8} \mathrm{Co}_{0.2} \mathrm{O}_{2}$ cathode (positive electrode) and DEC-EC-LiPF 6 electrolyte. Nine ATD baseline cells were fabricated by PolyStor, Inc. according to a design provided by Argonne National Laboratory (ANL) and tested at Idaho National Engineering and Environmental Laboratory (INEEL), ANL and Sandia National Laboratories (SNL). These cells were not optimized, and were used only in studies of cell components under high-power battery simulations.

High-current pulse profiles were generated specifically for performance characterization of these batteries in the hybrid electric vehicle applications in contrast to the constant-current profiles typically used in the characterization of lithium-ion batteries in portable devices. Nine 18650-size ATD cells were tested under a variety of conditions. All cells had undergone two formation cycles and one discharge, and some were placed on calendar-life tests (the cells were stored at various temperature) or cycle-life tests (the cell was subjected to a charge-neutral profile with 3,6, or 9\% variation of its state of charge) [21]. The power performance (W/kg) of all cells decayed by $15-30 \%$ during cycle-life and calendar-life testing. The cells were then discharged at the $\mathrm{C} / 25$ rate and stored at $10^{\circ} \mathrm{C}$. Cells were opened in a helium-atmosphere dry box, followed immediately by diagnostics.

In this paper we report results of diagnostic studies to characterize the cathodes taken from these cells. The goal of this study was to detect and characterize interfacial processes which occurred at the cathode/electrolyte interface and to determine their effect on the cathode electrochemical properties. Selected diagnostic techniques such as Raman spectroscopy, SERS, AFM and CSAFM were used to examine the surfaces of cathodes extracted from a fresh cell and cells after storage and cycle-life tests.

\section{EXPERIMENTAL}

(i) The thin-film $\mathrm{LiMn}_{2} \mathrm{O}_{4}$ electrodes were prepared by spin-coating of a homogeneous precursor solution onto a Pt substrate (about $1 \mathrm{~cm}^{2}$ ), a procedure similar to that reported in our previous paper [17]. The average film thickness of $300 \mathrm{~nm}$ was estimated from ellipsometric mesurements. X-ray diffraction patterns and Raman spectra of the $\mathrm{LiMn}_{2} \mathrm{O}_{4}$ thin films confirmed a cubic spinel structure with a $\mathrm{Fd} 3 \mathrm{~m}$ space symmetry group and a $0.819 \mathrm{~nm}$ cubic cell lattice parameter.

Electrochemical measurements were carried out in a polypropylene beaker-type cell at room temperature or $55^{\circ} \mathrm{C}$. Two separate pieces of $\mathrm{Li}$ foil were used as reference and counter electrodes. The electrolyte solution was commercial EC:DMC (1:1 by volume), $1 \mathrm{M} \mathrm{LiPF}_{6}$ purchased from EM Science. DMC was obtained from Grant Chemical Division Ferro Corporation. Cyclic voltammograms (CVs) were recorded with a Model $362 \mathrm{EG} \& \mathrm{G}$ scanning potentiostat at $1 \mathrm{mV} / \mathrm{s}$. Thin-film $\mathrm{LiMn}_{2} \mathrm{O}_{4}$ electrodes were exposed to pure DMC or the -EC+DMC (1:1 by volume), $1 \mathrm{M} \mathrm{LiPF}_{6}$ electrolyte at $60^{\circ} \mathrm{C}$ and $70^{\circ} \mathrm{C}$ for 1 day.

Ex-situ CSAFM images were obtained with a Molecular Imaging scanning probe microscope coupled with a Park Scientific Instruments (PSI) electronic controller. 
Platinum-coated Si microlevers $\left(0.12 \mathrm{Nm}^{-1}\right)$ were used to probe the local electrode conductance. Conductance images were recorded at $1.0 \mathrm{~V}$ sample-tip bias i.e., the electrode was positive vs. the tip. The CSAFM experiments were carried out in $\mathrm{N}_{2}$ atmosphere without exposing them to the air. Samples exposed to the electrolyte were rinsed with DMC and dried in $\mathrm{N}_{2}$ gas stream.

Ex-situ Raman and SERS spectra were recorded using a Coherent Inc. Model Innova 70 Argon ion laser at $\lambda=514.5 \mathrm{~nm}$, an HR320 spectrograph (Instruments SA Inc.), and an EG\&G multichannel analyzer Model 1463. The incident laser beam $(0.1$ x $3 \mathrm{~mm})$ power measured at the sample was adjusted to 5 and $30 \mathrm{~mW}$ for SER and regular Raman measurements, respectively.

In order to obtain SER spectra of $\mathrm{LiMn}_{2} \mathrm{O}_{4}$ electrode after exposure to DMC or electrolyte solution, half of the electrode surface was coated with fine Ag particles. Silver AC sputtering was conducted at $5 \times 10^{-2}$ bar vacuum, for $5 \mathrm{~s}$ at relatively low current (40 $\mathrm{mA}$ ). Raman and SER reference spectra of solid $\mathrm{Li}_{2} \mathrm{CO}_{3}, \mathrm{CH}_{3} \mathrm{COOLi}, \mathrm{NaHCO}_{3}$, $(\mathrm{COONa})_{2}$ and $\mathrm{HCOONa}$ were obtained in a similar manner i.e., thin films of crystalline salts were partially coated with silver microparticles and then their regular Raman and SER spectra recorded at ambient conditions.

(ii) The 18650-size ATD cell characteristics are listed in Table 1 and a summary of the test conditions for all nine cells is given in Table 2. Detailed description of testing parameters and diagnostic experimental procedures can be found in [22].

Table 1 Generation 1 Cell Components

\begin{tabular}{|l|l|l|}
\hline Component & Anode & Cathode \\
\hline active material & $\begin{array}{l}75 \% \text { MCMB graphite } \\
17 \% \text { SFG-6 carbon }\end{array}$ & $\begin{array}{l}84 \% \mathrm{LiNi}_{0.8} \mathrm{Co}_{0.2} \mathrm{O}_{2} \\
\text { Sumitomo }\end{array}$ \\
\hline binder & $\begin{array}{l}8 \% \text { polyvinylidene fluoride } \\
\text { Kurecha C }\end{array}$ & $\begin{array}{l}8 \% \text { polyvinylidene fluoride } \\
\text { Kurecha 1100 (homopolymer) }\end{array}$ \\
\hline additive & NA & $\begin{array}{l}4 \% \text { acetylene black, Shawinigan } \\
4 \% \text { graphite, SFG-6 }\end{array}$ \\
\hline current collector & $11 \mu \mathrm{m} \mathrm{Cu}$ foil & $28 \mu \mathrm{m} \mathrm{Al} \mathrm{foil-uncoated}$ \\
\hline loading & $5.5 \mathrm{mg} / \mathrm{cm}^{2}$ & $10.2 \mathrm{mg} / \mathrm{cm}^{2}$ \\
\hline separator & $37 \mu \mathrm{m} \mathrm{three-layer} \mathrm{(PE/PP/PE)} \mathrm{from} \mathrm{Celgard}$ \\
\hline electrolyte & $1 \mathrm{M} \mathrm{LiPF}$ in EC/DEC (1:1), LP-40 from EM Science (Merck) \\
\hline
\end{tabular}

Ex situ Raman spectra and CSAFM images were recorded using the instrumentation which was desribed in detaid in the above section.. AFM imaging was conducted in a small glove box specially designed for scanning-probe microscopy tests under a controlled $\mathrm{N}_{2}$ atmosphere. 
Table 2 Test conditions of the ATD GEN-1 cells

\begin{tabular}{|c|c|c|c|c|}
\hline Cell number & SOC & $\Delta$ SOC & Temp $\left({ }^{\circ} \mathrm{C}\right)$ & $\begin{array}{c}\text { Testing period } \\
\text { (weeks })\end{array}$ \\
\hline 1 & 0 & 0 & 20 & 0 \\
\hline 2 & 80 & 0 & 40 & 4 \\
\hline 3 & 60 & 0 & 50 & 12 \\
\hline 4 & 80 & 0 & 60 & 4 \\
\hline 5 & 60 & 0 & 70 & 2 \\
\hline 6 & 60 & 3 & 40 & 2 \\
\hline 7 & 60 & 3 & 70 & 4 \\
\hline 8 & 60 & 9 & 40 & 2 \\
\hline 9 & 60 & 9 & 70 & \\
\hline
\end{tabular}

\section{RESULTS}

\section{(i) Surface Layer Formation on a Thin-film $\mathrm{LiMn}_{2} \mathrm{O}_{4}$ Electrode}

Figure 1 shows CVs of the fresh thin-film $\mathrm{LiMn}_{2} \mathrm{O}_{4}$ electrode and electrodes exposed to pure DMC (a), and the electrolyte solution (b), at $60^{\circ} \mathrm{C}$ and $70^{\circ} \mathrm{C}$. Two anodic peaks at 4.05 and $4.17 \mathrm{~V}$ and two corresponding cathodic peaks at 4.03 and 3.90 $\mathrm{V}$ are characteristic for the $\mathrm{LiMn}_{2} \mathrm{O}_{4}$ spinel. The electrode exhibited moderate capacity loss of $0.2 \%$ per cycle over 43 cycles at room temperature.

A similar voltammetric curve was obtained for a $\mathrm{LiMn}_{2} \mathrm{O}_{4}$ electrode which was stored in pure $\mathrm{DMC}$ at $60^{\circ} \mathrm{C}$ for 1 day. Despite initially exhibiting $26 \%$ less capacity compared to the fresh $\mathrm{LiMn}_{2} \mathrm{O}_{4}$ electrode still showed good cycleability. However, storage of a $\mathrm{LiMn}_{2} \mathrm{O}_{4}$ electrode in pure DMC at $70^{\circ} \mathrm{C}$ led to its total deactivation. The fact that this degradation was not accompanied by even slight changes in its X-ray diffraction pattern suggests that the presence of a surface insulating layer is responsible for the observed loss of electrochemical activity.

Prolonged exposure of the $\mathrm{LiMn}_{2} \mathrm{O}_{4}$ electrode in the EC:DMC (1:1 by volume), $1 \mathrm{M}$ $\mathrm{LiPF}_{6}$ electrolyte led to irreversible destruction of the electrode. The higher the storage temperature, the greater the detrimental effect on the electrode
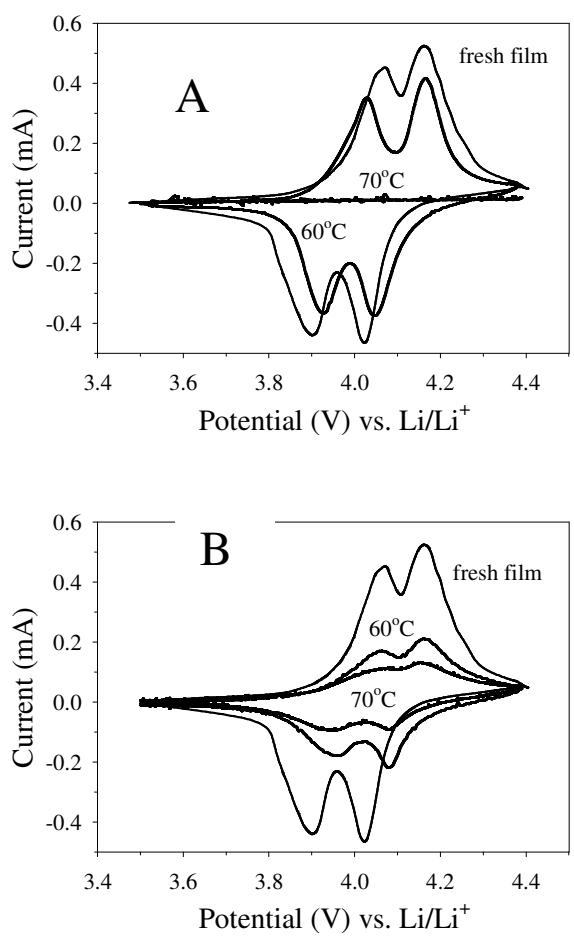

Figure 1. Cyclic voltammograms in $1 \mathrm{M} \mathrm{LiPF} 6-$ EC+DMC (1:1 by volume) of a fresh thin-film $\mathrm{LiMn}_{2} \mathrm{O}_{4}$ electrode and those exposed to DMC (a) and to the electrolyte solution (b) for 1 day at $60^{\circ} \mathrm{C}$ and $70^{\circ} \mathrm{C}$. Scan rate was $1 \mathrm{mV} / \mathrm{s}$ 
capacity was observed. The electrode capacity dropped to $49 \%$ and $32 \%$ after storage at 60 and $70^{\circ} \mathrm{C}$, respectively. Interestingly, the remaining active part of the electrode exhibited good cycleability and showed little capacity fading (3-4\%) after 43 cycles. One can expect that DMC decomposition followed by formation of an insulating surface layer may contribute to the observed decline of electrode capacity in this case. However, the surface film must be either non-uniform or penetrable by the electrolyte because the electrode still shows some electrochemical activity.

Figure 2 shows topographic (upper) and conductance (lower) images of a fresh thin-film electrode. The electrode surface morphology consists of densely packed grains with the average roughness ca. $24 \mathrm{~nm}$. The corresponding conductance image of the fresh $\mathrm{LiMn}_{2} \mathrm{O}_{4}$ electrode reveals non-uniform surface electronic conductivity. The brighter areas in the conductance images represent areas of relatively good conductivity whereas dark

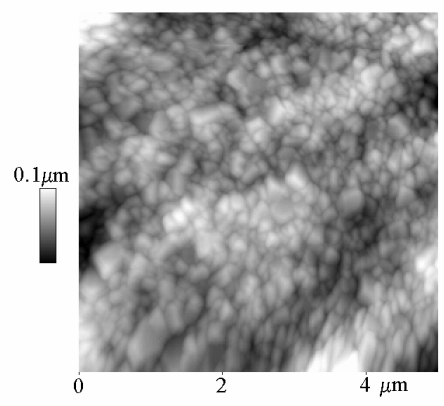

spots portray areas of poor conductivity. There are grains of active material which exhibit fairly good conductance, but we also found areas at the surface which show zero electronic conductivity. Interestingly, there are visible inhomogenities within single grains of $\mathrm{LiMn}_{2} \mathrm{O}_{4}$.

Figure 3 shows CSAFM images of $\mathrm{LiMn}_{2} \mathrm{O}_{4}$ electrodes exposed to pure DMC and the EC:DMC (1:1 by volume), $1 \mathrm{M} \mathrm{LiPF}_{6}$ electrolyte at 60 and $70^{\circ} \mathrm{C}$. Although the topographic image of the electrode exposed to pure

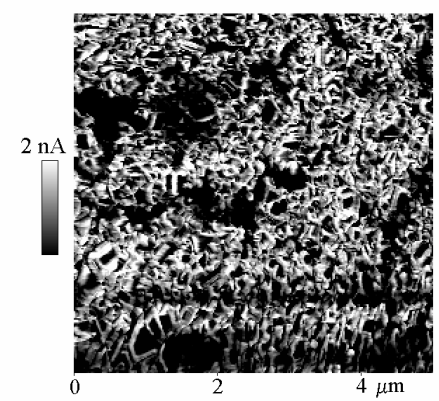
DMC at $60^{\circ} \mathrm{C}$ appeared very similar to that of the fresh electrode, the surface conductance decreased substantially over the entire surface. The surface smoothing effect combined with surface electronic conductivity loss may suggest either formation of an insulating surface layer and/or surface conversion of the $\mathrm{LiMn}_{2} \mathrm{O}_{4}$ into a non-conducting compound. When the thin-film electrode was exposed to Figure 2. CSAFM topographic (upper) and conductance (lower) images of a fresh thin-film $\mathrm{LiMn}_{2} \mathrm{O}_{4}$ electrode. Bright areas on the conductance image represent high conductivity locations.

pure DMC at $70^{\circ} \mathrm{C}$ the observed surface effects became even more pronounced. The average surface roughness decreased to $9 \mathrm{~nm}$ and surface conductance dropped to zero over the entire electrode surface.

CSAFM images of the thin-film $\mathrm{LiMn}_{2} \mathrm{O}_{4}$ electrode exposed to the electrolyte solution at $60^{\circ} \mathrm{C}$ show evidence of severe damage to the film structure. Formation of round pits of $\sim 1 \mu \mathrm{m}$ dia. and ca. 150 - $250 \mathrm{~nm}$ deep was detected, a clear indication of manganese dissolution. Surface conductance also dropped significantly at most of the surface, however, conductive spots were still present. Similarly to pure DMC, storage in the electrolyte at $70^{\circ} \mathrm{C}$ resulted in the complete loss of surface conductance of the thinfilm $\mathrm{LiMn}_{2} \mathrm{O}_{4}$ electrode. Examination of the corresponding topographic image reveals substantial changes in the electrode surface morphology and structural damage to the film. The size of pits grew larger to almost $2 \mu \mathrm{m}$ in diameter but they became 

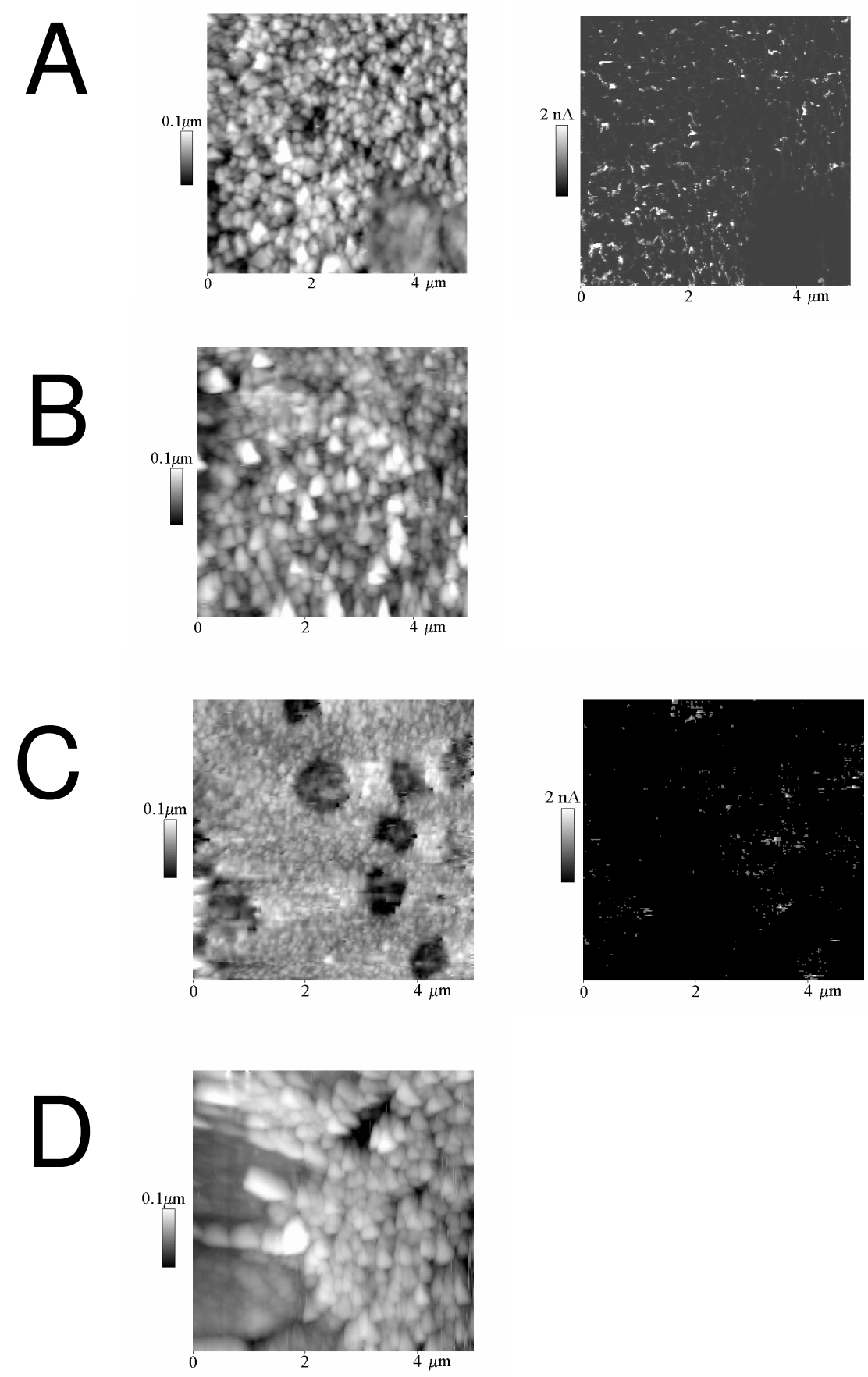

Figure 3 CSAFM topographic (left) and conductance (right) images of $\mathrm{LiMn}_{2} \mathrm{O}_{4}$ electrodes which were exposed to DMC and the electrolyte solution at elevated temperatures for 1 day. (A) DMC at $60^{\circ} \mathrm{C}$, (B) DMC at $70^{\circ} \mathrm{C}(\mathrm{C})$ electrolyte solution at $60^{\circ} \mathrm{C}$ (D) electrolyte solution at $70^{\circ} \mathrm{C}$. Bright areas on the conductance image represent high conductivity locations.

shallower compared to the electrode stored at $60^{\circ} \mathrm{C}$. Deep cracks in the $\mathrm{LiMn}_{2} \mathrm{O}_{4}$ film are also visible.

Figure 4 shows Raman and SER spectra of the fresh thin-film $\mathrm{LiMn}_{2} \mathrm{O}_{4}$ electrode, along with electrodes which were stored in pure DMC and in the electrolyte solution at $70^{\circ} \mathrm{C}$. A regular Raman spectrum of the fresh $\mathrm{LiMn}_{2} \mathrm{O}_{4}$ electrode consists of a series of broad bands between 300 and $700 \mathrm{~cm}^{-1}$. The peaks at 624,580 and $480 \mathrm{~cm}^{-1}$ are assigned to $A_{1 g}, T_{2 g}(3)$ and $T_{2 g}(2)$ phonons. The spectrum appears nearly identical to bulk-phase 
commercial $\mathrm{LiMn}_{2} \mathrm{O}_{4}$ powders available from chemicals suppliers.

When the $\mathrm{LiMn}_{2} \mathrm{O}_{4}$ electrode was exposed to pure $\mathrm{DMC}$ at $70^{\circ} \mathrm{C}$ a new feature at $656 \mathrm{~cm}^{-1}$ became visible. The band at $650 \mathrm{~cm}^{-1}$ was observed in the Raman spectra of hausmanite $\mathrm{Mn}_{3} \mathrm{O}_{4}$ and bixbyite $\mathrm{Mn}_{2} \mathrm{O}_{3}$. Because the intensities of bands at $624,580 \mathrm{~cm}^{-1}$ remained unchanged, the band at $656 \mathrm{~cm}^{-1}$ displays clearly $\mathrm{Mn}_{2} \mathrm{O}_{3}$ character. Taking into account that the light penetration depth for $\mathrm{LiMn}_{2} \mathrm{O}_{4}$ is limited to $30-50 \mathrm{~nm}$ and the fact that there is no evidence of a $\mathrm{Mn}_{2} \mathrm{O}_{3}$ phase in the $\mathrm{X}$-ray data, we postulate that only the electrode surface was enriched with $\mathrm{Mn}_{2} \mathrm{O}_{3}$ during storage in pure DMC at $70^{\circ} \mathrm{C}$.

The Raman spectrum of the electrode which was stored in the electrolyte at $70^{\circ} \mathrm{C}$ shows even more drastic changes. The sharp peak at $624 \mathrm{~cm}^{-1}$ vanished, and two bands at 580 and $650 \mathrm{~cm}^{-1}$ dominated the spectrum. The changes observed for the Raman spectrum of the $\mathrm{LiMn}_{2} \mathrm{O}_{4}$ electrode stored in the electrolyte can be largely explained in terms of at least partial delithiation and conversion to $\lambda-\mathrm{MnO}_{2}$. These results are fully consistent with our X-ray data.

For flat surfaces containing a thin adsorbed film, it is clear that even with an optimized system the Raman signal from the surface species will be very difficult to detect without enhancement mechanism of the Raman scattering. As a matter of fact, we could not observe any signal from the surface layer unless we sputtered a small amount of $\mathrm{Ag}$ nanoparticles on the electrodes. Interestingly, the SER spectra show new bands at $240,889,918,985 \mathrm{~cm}^{-1}$, broad multiband maxima centered around 1300 and $1600 \mathrm{~cm}^{-1}$, and a series of peaks in the $2100-2160 \mathrm{~cm}^{-1}$ region. These new bands, except for the peak at $918 \mathrm{~cm}^{-1}$, are not visible in the regular Raman spectra nor in the SER spectrum of the fresh film. Thus, they must have originated from the SEI layer. The broad band at $240 \mathrm{~cm}^{-1}$ can be assigned most likely to the lithiumoxygen stretch in lthium alkoxides Li-O$\mathrm{R}$ (R: alkyl) and/or lihium coordinated to a carboxylic $\mathrm{Li}-\left(\mathrm{CO}_{2}\right)-\mathrm{R}$ or carbonate group $(\mathrm{Li}-\mathrm{O})_{2}-\mathrm{C}=\mathrm{O}$. The broad peak maxima at 1300 and $1600 \mathrm{~cm}^{-1}$ correspond to symmetric and asymetric vibrations, respectively, of carboxyl and carbonate groups. The bands at 918 and 889,985 are probably C-C stretch and deformation vibrations of the carboxyl groups (-COO), respectively. The complex structure of these peaks suggests clearly a

A

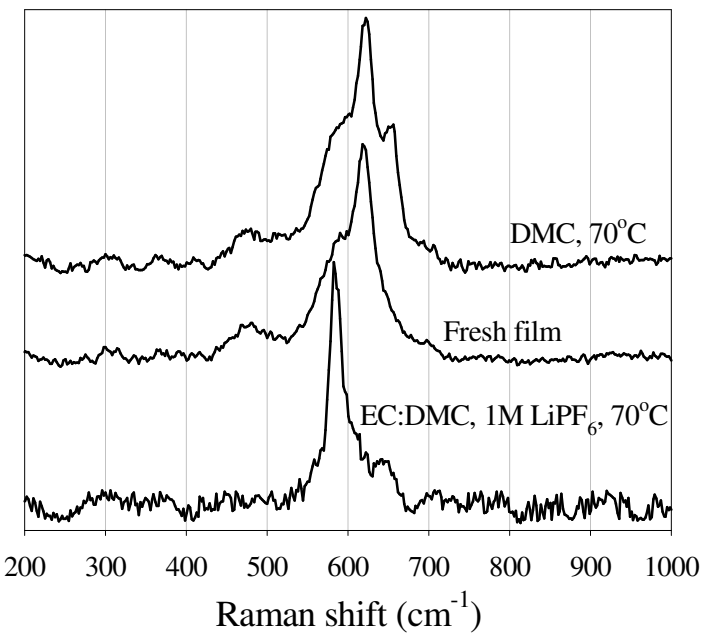

B

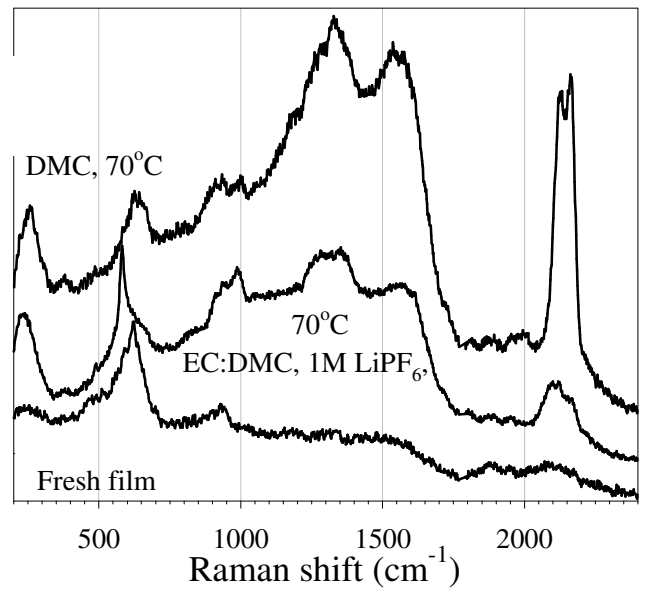

Figure 4. Regular (A) and SER spectra (B) of a fresh thinfilm $\mathrm{LiMn}_{2} \mathrm{O}_{4}$ electrode and $\mathrm{LiMn}_{2} \mathrm{O}_{4}$ electrodes exposed to $\mathrm{DMC}$ and the electrolyte solution at $70^{\circ} \mathrm{C}$ for 1 day 
non-uniform composition and symmetry of compounds which constitute the SEI layer. The double structure between 1300 and $1600 \mathrm{~cm}^{-1}$ in the SER spectra is usually attributed to surface carbonate species. Indeed, the features observed at reference Raman and SER spectra of $(\mathrm{COONa})_{2}, \mathrm{HCOONa}$, and $\mathrm{CH}_{3} \mathrm{COOLi}$ could not account for all the bands observed at the SER spectra of $\mathrm{LiMn}_{2} \mathrm{O}_{4}$ electrodes which were exposed to pure DMC and the electrolyte. The reference SER spectrum of $\mathrm{Li}_{2} \mathrm{CO}_{3}$ exhibits similar broad maxima at 1300 and $1600 \mathrm{~cm}^{-1}$ however it shows also sharp peaks at 1046 and $1084 \mathrm{~cm}^{-1}$ which are absent in the SER spectra of the SEIs. Moreover, none of the reference spectra showed such intense bands in the $2100-2160 \mathrm{~cm}^{-1}$ region. These features often accompany SER spectra from adsorbed molecules on silver as so-called "impurity lines". Because $\mathrm{CO}$ is only weakly bonded to silver at low temperatures $(120 \mathrm{~K})$, simple $\mathrm{CO}$ adsorption on silver must be ruled out. Instead, an interpretation based on stable CO-rich derived species reactively synthesized at the electrode surface from the oxygen reach SEI layer and reductive Ag particles during the sputtering seems more reasonable. The observed bands are located above and below $\mathrm{v}_{\mathrm{C}-\mathrm{O}}\left(2135 \mathrm{~cm}^{-1}\right)$ which suggest polynuclear carbonyl complexes being responsible for the observed spectral features. However, we must point out the preliminary character of the given interpretation.

In summary, thin-film $\mathrm{LiMn}_{2} \mathrm{O}_{4}$ electrodes were prepared by spin coating of a precursor solution onto a Pt substrate. The electrodes have spinel structure, and they exhibited electrochemical properties similar to powder $\mathrm{LiMn}_{2} \mathrm{O}_{4}$ electrodes. Insulating surface layers on electrodes exposed to pure DMC or to the EC:DMC, $1 \mathrm{M} \mathrm{LiPF}_{6}$ electrolyte solution at temperatures above $60^{\circ} \mathrm{C}$ were detected by CSAFM and SERS measurements. It originated from DMC surface oxidation by $\mathrm{Mn}(\mathrm{IV})$. The SEI layer formation was accompanied by conversion of the original $\mathrm{LiMn}_{2} \mathrm{O}_{4}$ into $\mathrm{Mn}_{2} \mathrm{O}_{3}$ and $\lambda$ $\mathrm{MnO}_{2}$ in pure DMC and the electrolyte, respectively. The surface layer formed in pure DMC at $70^{\circ} \mathrm{C}$ was electronically insulating and it led to complete deactivation of the electrode. A similar layer formed on the surface of the spinel electrode in the electrolyte solution, however, the electrode surface sustained serious structural damage and a large amount of manganese dissolved into the solution. Formation of the surface layer and active material loss are responsible for the observed capacity decline in this case. SER spectra showed that the surface layer contains alkoxide, carboxylic and carbonate functional groups in a complex, polymer-type structure derived from various nucleophilic reactions between $\mathrm{LiMn}_{2} \mathrm{O}_{4}$ and DMC and/or its intermediates

\section{(i) Temperature-induced surface degradation of $\mathrm{LiNi}_{0.8} \mathrm{Co}_{0.2} \mathrm{O}_{2}$ cathodes.}

Figure 5 shows topographic AFM images of the cathode extracted from Cell 1 (a), and Cell 7 (b) (see Table 2) which was cycled at $70^{\circ} \mathrm{C}$ at $60 \%$ SOC and $3 \% \Delta$ SOC. Examination of the topographic AFM images of the cathode that was extracted from the cell cycled at $70^{\circ} \mathrm{C}$ (Fig. 5b) reveals a significant change in the surface morphology. The initial large and flat grains of active material are still recognizable, but the entire surface is now covered by nanocrystalline deposits. The individual particles sizes varied from 50 to $200 \mathrm{~nm}$. Considerable amounts of this deposit accumulated, particularly in the intergranular spaces, however the nanoparticles can also be found scattered randomly across the crystal planes of the active material. 

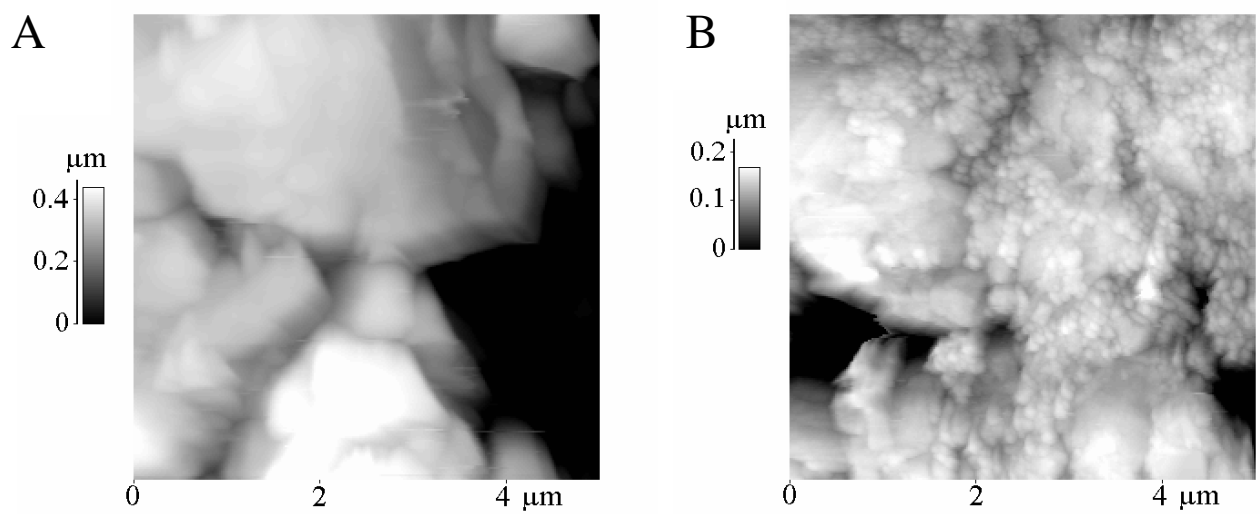

Figure 5. AFM topographic images of cathodes from the (a) Cell 1, and (b) Cell 7 (cycled at $70{ }^{\circ} \mathrm{C}$ at $60 \%$ SOC and $3 \% \Delta$ SOC)

Interestingly, we found a similar type of deposit on the surfaces of almost all cathodes from cells that were subjected to either the calendar-life or life-cycle tests. In order to quantify the AFM results and identify a clear relationship between the cathode surface morphology changes and the testing temperature, a statistical analysis of the AFM images was carried out. Figure 6 shows the surface-average and rms roughness parameters expressed versus temperature. The results at $20^{\circ} \mathrm{C}$ correspond to the uncycled Cell no.1. It is clear from Fig. 5 that both surface roughness parameters decrease monotonically with increasing temperature. This trend is consistent with visual observations from the AFM images. The nanocrystalline deposit, which accumulated preferentially in deep cavities between the grains of active material, smoothed the surface to some extent. The decreasing gap between the surface-average and rms roughness values at higher temperatures suggests the formation of a more uniform surface with less protrusions and deep crevices. Interestingly, the smoothing effect was more pronounced in the calendar-life cells compared to the cycled cells. Such behavior suggests a precipitation mechanism of deposit formation rather than an electrochemical dissolution/redeposition process.

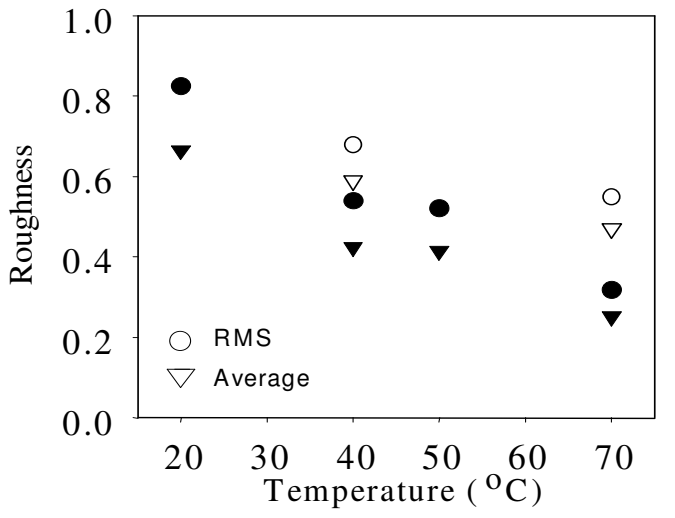

Figure 6. Surface-average and rms roughness parameters of cathodes from the virgin cell (no. 1), calendar-life cells no.2, 3, 5 (filled symbols) cycled cells no. 6 and 7 (open symbols) expressed versus temperature

To gain additional insight into the nature of the nanocrystalline deposit we studied the cathode surface with Raman spectroscopy. Figure 7 shows Raman spectra of cathodes from Cells 1 (a) and 3 (b). The Raman spectra of both cathodes are dominated by two strong and broad carbon bands at 1365 and $1580 \mathrm{~cm}^{-1}$ and a broad maximum centered around $500 \mathrm{~cm}^{-1}$, characteristic for $\mathrm{LiNi}_{\mathrm{x}} \mathrm{Co}_{1-\mathrm{x}} \mathrm{O}_{2}$ oxide. Close examination of the Raman bands that arise from $\mathrm{LiNi}_{\mathrm{x}} \mathrm{Co}_{1-\mathrm{x}} \mathrm{O}_{2}$. reveals that almost all cathodes which were tested at 
higher temperatures exhibit an intense peak at $558 \mathrm{~cm}^{-1}$. This band, along with the band at $480 \mathrm{~cm}^{-1}$, is usually associated with vibrations characteristic of $\mathrm{Ni}$ (III) and/or $\mathrm{Ni}(\mathrm{IV})$ oxides, and their presence can be detected in the spectrum of fresh cathodes. However, the rise of their intensities suggests selective dissolution of cobalt from the $\mathrm{LiNi}_{x} \mathrm{Co}_{1-\mathrm{x}} \mathrm{O}_{2}$ or the formation of a separate phase of nickel oxide at the cathode surface. The presence of a nanocrystalline deposit at the cathode surface supports this hypothesis. Mid-IR (wave number range $600-4000 \mathrm{~cm}^{-1}$ ) data revealed no observable SEI layer on the cathode surface, which suggests the precipitate does not arise from oxidation of the electrolyte. We may assume that in the long term such phase changes combined with extensive electrode surface morphology modifications can lead to significant electrode degradation and eventual failure.

\section{ACKNOWLEDGMENT}

This work was supported by the Director, Office of Science, Office of Basic Energy Sciences, Chemical Sciences Division; and by the Assistant Secretary for Energy Efficiency and Renewable Energy, Office of Advanced Automotive Technologies, U. S. Department of Energy, under contract number DE- AC03-76SF00098

\section{REFERENCES}

1. P. Arora, R. E. White and M. Doyle, J. Electrochem. Soc., 145, 3647 (1998)

2. G. Amatucci, A. Du Pasquier, A. Blyr, T. Zhang and J.-M. Tarascon, Electrochim. Acta, 45, 255 (1999)

3. R. J. Gummow, A. de Kock and M. M. Thackeray, Solid State Ionics, 69, 59 (1994)

4. J. M. Tarascon, W. R. McKinon, F. Coowar, T. N. Bowmer, G. Amatucci, D. Guyomard and M. M. Thackeray, J. Electrochem. Soc., 141, 1421 (1994)

5. S. J. Wen, T. J. Richardson, L. Ma, K. A. Striebel, P. N. Ross and E. J. Cairns, J. Electrochem. Soc., 143, L136 (1996)

6. D. H. Jang, J. Shin and S. M. Oh, J. Electrochem. Soc., 143, 2204 (1996)

7. Y. Xia, Y. Zhou and M. Yoshio, J. Electrochem. Soc., 144, 2593 (1997)

8. D. H. Jang and S. M. Oh, J. Electrochem. Soc., 144, 3342 (1997)

9. D. H. Jang and S. M. Oh, Electrochim. Acta, 43, 1023 (1998)

10. A. Blyr, C. Sigala, G. Amatucci, D. Guyomard, Y. Chabre and J-M. Tarascon, J. Electrochem. Soc., 145, 194 (1998)

11. M. M. Thackeray, Y. S-Horn, A. J. Kahaian, K. D. Kepler, E. Skinner, J. T. Vaughey and S. A. Hackney, Electrochem. and Solid State Lett., 1, 7 (1998) 
12. O. Shilling and J. R. Dahn, J. Electrochem. Soc., 144, 2593 (1998)

13. A. Du Pasquier, A. Blyr, P. Courjal, D. Larcher, G. Amatucci, B. Gerand and J-M. Tarascon, J. Electrochem. Soc., 146, 428 (1999)

14. A. Du Pasquier, A. Blyr, A. Cressent, C. Lenain, G. A. Amatucci and J. M. Tarascon, J. Power Sources, 81-82, 54 (1999)

15. J. Cho and M. M. Thackeray, J. Electrochem. Soc., 146, 3577 (1999)

16. H. Huang, C. A. Vincent and P. Bruce, J. Electrochem. Soc., 146, 481 (1999)

17. R. Kostecki, F. Kong, Y. Matsuo and F. McLarnon, Electrochim. Acta, 45, 225 (1999)

18. T. Inoue and M. Sano, J Electrochem. Soc., 145, 3704 (1998)

19. G. Pistoia, A. Antonini, R. Rosati and D. Zane, Electrochim. Acta, 41, 2683 (1996)

20. D. Aurbach, K. Gamolsky, B. Markovsky, G. Salitra, Y. Gofer, U. Heider, R. Oesten and M. Schmidt, J. Electrochem.Soc., 147, 1322 (2000)

21. ATD test plan for ATD 18650 GEN 1 lithium ion cells, Revision 4, December 8, 1999, INEEL

22. X. Zhang, P. N. Ross, Jr., R. Kostecki, F. Kong, S. Sloop, J. B. Kerr, K. Striebel, E. J. Cairns and F. McLarnon, J. Electrochem. Soc., submitted 